\title{
Do Learners Really Know Best? Urban Legends in Education
}

Citation for published version (APA):

Kirschner, P. A., \& van Merrienboer, J. J. G. (2013). Do Learners Really Know Best? Urban Legends in Education. Educational Psychologist, 48(3), 169-183. https://doi.org/10.1080/00461520.2013.804395

Document status and date:

Published: 01/07/2013

DOI:

10.1080/00461520.2013.804395

Document Version:

Publisher's PDF, also known as Version of record

Document license:

Taverne

Please check the document version of this publication:

- A submitted manuscript is the version of the article upon submission and before peer-review. There can be important differences between the submitted version and the official published version of record.

People interested in the research are advised to contact the author for the final version of the publication, or visit the DOI to the publisher's website.

- The final author version and the galley proof are versions of the publication after peer review.

- The final published version features the final layout of the paper including the volume, issue and page numbers.

Link to publication

\footnotetext{
General rights rights.

- You may freely distribute the URL identifying the publication in the public portal. please follow below link for the End User Agreement:

www.umlib.nl/taverne-license

Take down policy

If you believe that this document breaches copyright please contact us at:

repository@maastrichtuniversity.nl

providing details and we will investigate your claim.
}

Copyright and moral rights for the publications made accessible in the public portal are retained by the authors and/or other copyright owners and it is a condition of accessing publications that users recognise and abide by the legal requirements associated with these

- Users may download and print one copy of any publication from the public portal for the purpose of private study or research.

- You may not further distribute the material or use it for any profit-making activity or commercial gain

If the publication is distributed under the terms of Article $25 \mathrm{fa}$ of the Dutch Copyright Act, indicated by the "Taverne" license above, 


\section{Do Learners Really Know Best? Urban Legends in Education}

\section{Paul A. Kirschner \& Jeroen J.G. van Merriënboer}

To cite this article: Paul A. Kirschner \& Jeroen J.G. van Merriënboer (2013) Do Learners Really Know Best? Urban Legends in Education, Educational Psychologist, 48:3, 169-183, DOI: 10.1080/00461520.2013.804395

To link to this article: https://doi.org/10.1080/00461520.2013.804395

曲 Published online: 14 Jun 2013.

Submit your article to this journal $\widetilde{T}$

Џlll Article views: 39553

Q View related articles $₫$

4 Citing articles: 105 View citing articles 


\title{
Do Learners Really Know Best? Urban Legends in Education
}

\author{
Paul A. Kirschner \\ Centre for Learning Sciences and Technologies \\ Open University of The Netherlands \\ Jeroen J. G. van Merriënboer \\ Department of Educational Development \& Research and Graduate School \\ of Health Professions Education \\ Maastricht University
}

\begin{abstract}
This article takes a critical look at three pervasive urban legends in education about the nature of learners, learning, and teaching and looks at what educational and psychological research has to say about them. The three legends can be seen as variations on one central theme, namely, that it is the learner who knows best and that she or he should be the controlling force in her or his learning. The first legend is one of learners as digital natives who form a generation of students knowing by nature how to learn from new media, and for whom "old" media and methods used in teaching/learning no longer work. The second legend is the widespread belief that learners have specific learning styles and that education should be individualized to the extent that the pedagogy of teaching/learning is matched to the preferred style of the learner. The final legend is that learners ought to be seen as self-educators who should be given maximum control over what they are learning and their learning trajectory. It concludes with a possible reason why these legends have taken hold, are so pervasive, and are so difficult to eradicate.
\end{abstract}

Mark Twain, speaking about religion and politics, lamented the fact that people's beliefs and convictions are usually second-hand, taken without examination from others who have not themselves examined the questions at issue but have taken them second-hand from other nonexaminers. He concludes that these opinions are "not worth a brass farthing" (Twain, 1910/2010). Today, unfortunately, this appears also to be true for education. We hear many claims as to what is wrong with education, what is needed to correct those wrongs, and why this is the case. Many of the claims, regrettably, are based on belief rather than science and have become tenacious urban legends used by instructional designers, curriculum reformers, politicians, school administrators, and advisory groups all vying for position to show how innovative and up to date they can be.

Correspondence should be addressed to Paul A. Kirschner, Centre for Learning Sciences and Technologies, Open University of The Netherlands, Valkenburgerweg 177, 6419AT Heerlen, The Netherlands. E-mail: paul.kirschner@ou.nl

\section{URBAN LEGENDS IN EDUCATION}

Most of us have heard about the alligator that attacked a sewer worker in New York City. The story goes that some child's mother threw down the toilet a baby alligator that her child had gotten as a present from the grandparents who were vacationing in Florida. In the warm, wet sewers of New York City it grew to a length of 15 feet and attacked a sewer worker carrying out routine maintenance work. This is a classic example of an urban legend - a story that is held to be true, sounds plausible enough to be believed, is based primarily on hearsay, and is widely circulated as true. But what about the generation of children whose brains have evolved such that they can multitask? The story goes that today's children ...

What follows are three contemporary beliefs about learners and their learning that the authors classify as urban legends. These beliefs, though both popular and pervasive in education and educational policy, do not really concur with the body of research in educational psychology. They are discussed from the perspective of the central idea that learners 
know best how to (a) deal with new technologies for learning ("learners as digital natives"), (b) adapt learning to their own preferred learning styles ("learners as having specific learning styles"), and (c) select and order learning contents ("learners as self-educators"). These legends are so strong and widespread that there is little that a teacher can do to counteract the negative effects that implementation of these legends brings with them. To this end, this article presents a discussion of the legends that is strongly grounded in a diverse array of evidence, including ecologically valid evidence from field studies. As such, the authors make the case for using solid, evidence-based methods and research results in education so as not to succumb to "good sounding" myths, trends, and fads (i.e., urban legends).

\section{LEARNERS AS DIGITAL NATIVES}

The first legend is that we have a new generation of children known as digital natives for whom "learning is playing," where "school is for meeting friends rather than learning" and who have the "skill to construct meaningful knowledge from discontinued audio-visual and textual information flows" (Veen, 2006; Veen \& Vrakking, 2006). These children are creative problem solvers, experienced communicators, self-directed learners, and digital thinkers (Veen, 2006) who have developed the ability to do many different things at the same time that require conscious thought processes (e.g., work on their homework, chat online or text message with friends, update their Facebook page, etc.). These assumptions are all grounded - at least partly - in the widespread belief that children are highly effective at managing their own interactions with the technological world and should be trusted to be in control of these interactions.

In the following subsections, this is discussed as well as the evidence refuting it. We first discuss the notion that students are highly information-competent digital natives and then the idea that students are able to effectively multitask with various technologies.

\section{Homo Zappiens}

Prensky $(2001,2006)$ coined the term digital native to refer to a group of young people who have been immersed in technology all their lives, giving them distinct and unique characteristics that set them apart from previous generations and who have sophisticated technical skills and learning preferences for which traditional education is unprepared. Prensky's coining of the term was not based upon research into this generation and careful study of them, but rather by rationalizing the phenomena that he had observed (e.g., he saw kids "surrounded by and using computers, videogames, digital music players, video cams, cell phones, and all the other toys and tools of the digital age"; Prensky, 2001, p. 1) and assuming that (a) they really understood what they were do- ing, (b) were using them effectively and efficiently, and (c) it is good to design education where they can do this. ${ }^{1}$

Veen and Vrakking (2006) introduced the term homo zappiens to refer to a new generation of learners who, unlike their predecessors, learn in a significantly different way. The term can be compared with others given to the generation that does not know a world without computers, mobile phones, and the Internet, such as the Net generation (Oblinger \& Oblinger, 2005; Tapscott, 1997), Generation I or iGeneration (Rosen, 2007), Google Generation (Rowlands et al., 2008), and so forth. Rosen (2009) presented research data showing that 13to 15 -year-olds spend, on average, $15 \mathrm{hr} 47 \mathrm{~min}$ a day using technology and media. He reached this number by adding parents' self-report of different media and technology usage for the activities: on computer, online, e-mail, instant messaging/chat, texting, television, video games, music, and telephone. In other words a child who spends $2 \mathrm{hr}$ e-mailing while the radio is on is characterized as spending $8 \mathrm{hr}$ using technology and media ( $2 \mathrm{hr}$ on computer $+2 \mathrm{hr}$ online $+2 \mathrm{hr}$ emailing $+2 \mathrm{hr}$ listening to the radio). According to Veen and Vrakking, children in this generation develop - on their own and without instruction - the metacognitive skills necessary for inquiry-based learning, discovery-based learning, networked learning, experiential learning, collaborative learning, active learning, self-organization and self-regulation, problem solving, and making their own implicit (i.e., tacit) and explicit knowledge explicit to others.

The first question is, Does such an information technology savvy generation actually exist? Margaryan, Littlejohn, and Vojt (2011) reported that university students (i.e., members of the Net generation) use a limited range of technologies for learning and socialization: "The tools these students used were largely established technologies, in particular mobile phones, media player, Google, Wikipedia. The use of handheld computers as well as gaming, social networking sites, blogs and other emergent social technologies was very low" (p. 38). A number of research studies (Bullen, Morgan, Belfer, \& Qayyum, 2008; Ebner, Schiefner, \& Nagler, 2008; Kennedy et al., 2007; Kvavik, 2005) in different countries (e.g., Austria, Australia, Canada, Switzerland, the United States) question whether the Homo Zappiens and/or Digital Native really exists. These researchers found that university students do not really have deep knowledge of technology, and what knowledge they do have is often limited to basic office suite skills, e-mailing, text messaging, Facebook, and surfing the Internet. According to Bullen et al. (2008), "it appears they [university students] do not

\footnotetext{
${ }^{1}$ A noteworthy aspect of Prensky's claim is the quote from Dr. Bruce D. Perry, Baylor College of Medicine, directly under the title and byline. There he is quoted as saying that "different kinds of experiences lead to different brain structures." This citation has been used as "proof" that digital natives exist by many writers and websites, but - unfortunately - the person that probably is alluded to is Dr. Bruce B. Perry, clinical researcher of long-term effects of trauma in children, adolescents, and adults and who was professor of psychiatry at Baylor until 2001!
} 
recognize the enhanced functionality of the applications they own and use" (p. 7.7) and that significant further training in how technology can be used for learning and problem solving is needed. When used for learning, this was mostly for passive consumption of information (e.g., Wikipedia) or for downloading lecture notes. A report commissioned by the British library and JISC (P. Williams \& Rowlands, 2007) also overturns the common assumption that the Google generation is the most web literate. Rowlands et al. (2008) concluded "that much professional commentary, popular writing and PowerPoint presentations overestimates the impact of ICTs on the young, and that the ubiquitous presence of technology in their lives has not resulted in improved information retrieval, information seeking or evaluation skills" (p. 308).

What we may actually be seeing is a generation where learners at the computer behave as butterflies fluttering across the information on the screen, touching or not touching pieces of information (i.e., hyperlinks), quickly fluttering to a next piece of information, unconscious to its value and without a plan. This butterfly defect was first signaled by Salomon and Almog (1998). Learners are seduced (Harp \& Mayer, 1997; Mayer, 2005) into clicking the links, often forgetting what they are looking for. This "fluttering" leads - at best - to a very fragile network of knowledge. Many a quest ends in a quagmire of possibly interesting but irrelevant pieces of information.

Related to this, a recent study by Valtonen et al. (2011) of what they called Finnish Net Generation student teachers (i.e., student teachers born in the period 1984-1989) showed "that the technological knowledge of student teachers is not what would be expected for representatives of the Net Generation" (pp. 13-14). In the study, they explored technological pedagogical knowledge, which they defined as the "understanding of the benefits and disadvantages of various technologies related to different pedagogical aims and practices" (p. 7). Although it was expected that these Net Generation students would be adept at learning through discovery and thinking in a hypertext-like manner (Oblinger \& Oblinger, 2005 ) and that they would be able to transfer those skills to their teaching practices upon entering the teaching profession (Prensky, 2001), the results showed, just like the results of Margaryan et al. (2011) and Bullen et al. (2008), that the range of software used was very limited and that, for example, social media was used as a passive source of information and not as a tool for actively creating content, interacting with others, and sharing resources. Valtonen et al. concluded that the expectations and assumptions about this group of "student teachers' abilities to adopt and adapt ICT in their teaching are highly questionable" (p. 1).

Selwyn (2009) carried out a thorough review of recently published literature on young people and digital technology in information sciences, education studies, and media/communication studies. He determined that young people's engagement with digital technologies is varied and often unspectacular, in contrast to popular portrayals of these so- called digital natives. In a critical review of evidence relating to what they called the digital native debate, Bennett, Maton, and Kervin (2008) went even further, arguing "that rather than being empirically and theoretically informed, the debate can be likened to an academic form of a "moral panic"' ( $p$. 782). They concluded that their "analysis of the digital native literature demonstrates a clear mismatch between the confidence with which claims are made and the evidence for such claims" (p. 782). A salient side note here is that although the concept of the digital native explicitly and/or implicitly assumes that the current generation of children is digitally literate, many curricula (e.g., Iowa Department of Education) see information and technology literacy as 21 st-century skills that are core curriculum goals at the end of the educational process and that need to be acquired.

\section{Multitaskers}

A second aspect of the urban legend that modern students are digital natives (and thus well able to control their own learning with technology) is that students are highly efficacious multitaskers. Because children are observed doing their homework, instant messaging, surfing the web, and so forth, in a way that seems as if they are doing all of this simultaneously, the observer often assumes (a) that these children are actually multitasking, and (b) that they are doing this without any loss of efficiency or effectiveness. This assumption is often supplemented with statements that this is different from what previous generations could do and thus that there has been a specific change in their brains to allow this. S. Anderson (2009), in discussing what he called "the benefits of distraction," opted that children "growing up now might have an associative genius we don' $t$ - a sense of the way ten projects all dovetail into something totally new." According to Small (Lin, 2008), author of popular books such as iBrain: Surviving the technological alteration of the modern mind, exposure to digital media is rewiring the neural circuitry of children's brains, heightening skills like multitasking, complex reasoning, and decision making.

With the term multitasking, people mean the simultaneous and/or concurrent performance of two or more tasks requiring cognition or information processing (e.g., attending to the road while driving and simultaneously talking on a cell phone). The problem here is that human cognitive architecture and brain functioning only allows for switching between different tasks (i.e., performing a number of different tasks or partial tasks in quick succession) rather than the simultaneous performance of tasks, even though the performance seems subjectively to occur simultaneously. Human beings can do more than one thing at any one time only when what they are doing is fully automated (e.g., walking and talking at the same time though even this can lead to falls and other accidents; Herman, Mirelman, Giladi, Schweiger, \& Hausdorff, 2011). When thinking or conscious information processing 
plays a role, people are not capable of multitasking and can, at best, switch quickly from one activity to another.

When task switching, first the individual shifts the goal and thus makes a "decision" to divert attention from one task to another, and then the individual activates a rule so instructions for executing one task are switched off, and those for executing the other are switched on. This so-called multitasking involves dividing one's attention between the tasks, and because each task competes for a limited amount of cognitive resources, the performance of one interferes with that of the other. This interference has been shown at the cognitive, information-processing level in many empirical studies by Brumby and colleagues across a time span of 10 years on the intersection of human-computer interaction and cognitive science (e.g., Brumby \& Salvucci, 2006; Brumby, Salvucci, \& Howes, 2009; Janssen, Brumby, Dowell, \& Chater, 2010). According to Brumby and Salvucci (2006), for example,

Constraints on the human cognitive architecture often limit perfect task parallelism during such multitasking situations. As a consequence, task operators must be interleaved ... there is a central cognitive bottleneck that operates to limit performance and that control between two or more primary tasks must be passed through a queuing mechanism. (p. 2451)

This interference has also been shown at the neural level (Dux, Ivanoff, Asplund, \& Marois, 2006; Tombu et al., 2011). Dux, head of the cognitive neuroscience lab in the School of Psychology at the University of Queensland Australia, concluded,

When humans attempt to perform two tasks at once, execution of the first task leads to postponement of the second one. This task delay is thought to result from a bottleneck occurring at a central, amodal stage of information processing that precludes two response selection or decision-making operations from being concurrently executed. (p. 1109)

What people really mean when they say that current generation is good at multitasking is that the current generation has, through practice, seemingly developed the ability to quickly switch between different tasks or different media. Unfortunately, though they do this, this does not mean that it is beneficial or positive for them to do this or that it is beneficial for learning (i.e., that the learning occurs more effectively or efficiently) and/or that it is not harmful for their accurately carrying out those tasks. It has been broadly shown that rapid switching behavior, when compared to carrying out tasks serially, leads to poorer learning results in students and poorer performance of tasks (Rogers \& Monsell, 1995; Rubinstein, Meyer, \& Evans, 2001). This is primarily due to the fact that switching requires a person to juggle her or his limited cognitive resources to accomplish the different tasks successfully. This juggling leads to greater inefficiency in performing each individual task, namely, that more mistakes are made and it takes significantly longer as compared to sequential work.
According to Meyer, professor and chair of Cognition \& Cognitive Neuroscience and director of the Brain, Cognition and Action Lab at the University of Michigan (Wallis, 2006),

If a teenager is trying to have a conversation on an e-mail chat line while doing algebra, she'll suffer a decrease in efficiency, compared to if she just thought about algebra until she was done. People may think otherwise, but it's a myth. With such complicated tasks [you] will never, ever be able to overcome the inherent limitations in the brain for processing information during multitasking.

This has also been shown to be the case when experts (i.e., doctors with high levels of expertise) are required to switch between tasks, for example, in a hospital emergency room. The increased burden of memory load resulting from the need to combine multiple, simultaneous tasks and deal with numerous interruptions has been found to result in an increase in the number of medical errors (Coiera, Jayasuria, Hardy, Bannan, \& Thorpe, 2002; Laxmisan et al., 2007).

In a novel comparison between people driving, driving while legally drunk, and driving while talking on the cell phone (hands free and hand held), Strayer, Drews, and Crouch (2006) found that

drivers using a cell phone exhibited a delay in their response to events in the driving scenario and were more likely to be involved in a traffic accident. Drivers in the alcohol condition exhibited a more aggressive driving style, following closer to the vehicle immediately in front of them, necessitating braking with greater force. With respect to traffic safety, the data suggest that the impairments associated with cell phone drivers may be as great as those commonly observed with intoxicated drivers. (p. 388)

In a learning setting, Fox, Rosen, and Crawford (2009) demonstrated that whereas reading comprehension of graduate students using instant messaging while reading was equal to that of students not using instant messaging, students using instant messaging took significantly longer to complete the different comprehension tests used and took significantly longer to read the passage given to them than those not using instant messaging. The differences in time ranged from 1.53 to 1.77 times as long for the tests and 1.66 times as long for the reading. In other words, though equal comprehension can be achieved, the time needed for this is significantly longer. The time difference is negligible for short texts such as those used in the experiment $(5.53 \mathrm{~min}$ vs. $3.33 \mathrm{~min}$ ), but what would the time difference become if the assignment were a normal university reading assignment?

It is not only the case that interrupting the completion of one task by another task leads to increases in time spent on a task. Interruptions and distractions have also been found to be one of the most common causes of pilot error. Dismukes, Young, and Sumwalt (1998), for example, determined that half of the instances of crew error involved lapses of 
attention caused by interruptions, distractions, or another task interfering with the task being carried out. Interruptions were also found to be one of the major factors contributing to drug dispensing errors by pharmacists (Peterson, Wu, \& Bergin, 1999) and nurses (Gladstone, 1995).

Finally, if one stretches the term "multitasking" to mean better ability in task switching, the picture gets even grimmer. Ophir, Nass, and Wagner (2009) observed that

heavy media multitaskers are more susceptible to interference from irrelevant environmental stimuli and from irrelevant representations in memory. This led to the surprising result that heavy media multitaskers performed worse on a test of task-switching ability, likely because of reduced ability to filter out interference from the irrelevant task set. (p. 15583)

In conclusion there is strong evidence that multitasking and task switching impair performance and learning, and there is no reason to expect positive effects of educational methods that require multitasking.

To conclude, there is overwhelming evidence that the homo zappiens and the multitasker do not exist, that they are not capable of doing that with modern technologies which is ascribed to their repertoire (i.e., the digital native may live in a digital age and world but cannot properly navigate that world for learning) and that they actually may "suffer" if teaching and education tries to play into these so-called abilities to relate to, work with, and control their own learning in multimedia and digitally pervasive environments.

\section{LEARNERS AND THEIR LEARNING STYLES}

A second legend is that all learners are aware of their own personal learning style and that good instruction requires diagnosing the learning style of each individual and aligning instruction accordingly. Because of this pervasive belief, administrators, teachers, parents, and even learners trust too much in the learners' supposed ability to manage/control their own learning. For example, people are believed to be visual/verbal learners (Richardson, 1977), impulsive/reflective learners (Kagan, 1965), holistic/analytical learners (Beyler \& Schmeck, 1992), or learners with any other style (for an overview of learning styles, see Cassidy, 2004; Coffield, Moseley, Hall, \& Ecclestone, 2004). The assumption is that teachers or instructional material developers should take their learners' preferred styles into account so as to facilitate their learning and help them reach best possible learning outcomes. This idea is intuitively appealing and has high face validity. Thousands of articles and books have been written on learning styles and their application in education. Furthermore, a lucrative commercial industry has been set up around (a) selling measurement instruments meant to help teachers diagnose their students' learning styles and (b) holding workshops and conferences meant to provide information and training to teachers on how to align their teaching to the learning styles of their students. Yet there are fundamental problems with regard to both the diagnosis of learning styles and the alignment of instruction to these styles. The following subsections discuss these problems and provide arguments and evidence against the use of learning styles in education, given the scientific evidence currently available.

\section{Learners in Pigeonholes}

Most learning styles are based on types, meaning that they do not assign people scores on different dimensions but classify people into distinct groups. The assumption that people cluster into distinct groups, however, receives very little support from objective studies (e.g., Druckman \& Porter, 1991). There are at least three problems with putting learners in pigeonholes: Many people do not fit one particular style, the information used to assign people to styles is often inadequate, and there are so many different styles that it becomes cumbersome to link particular learners to particular styles.

First, most differences and especially differences in cognition between people are gradual rather than nominal. Many learning styles neglect this finding by using an arbitrary criterion (e.g., a median or mean) to assign people to groups. For example, the learning style "reflection-impulsivity" (for a review, see Messer, 1976) is typically measured by the Matching Familiar Figures Test (Kagan, Rosman, Day, Albert, \& Phillips, 1964; for a computerized version, see van Merriënboer, Jelsma, Timmermans, \& Sikken, 1989). In this test, standard pictures are presented together with eight alternatives of which only one is identical to the standard. A match of the alternatives to the standard is required for all items of the test. Time in seconds to first response and number of errors are registered for each item. A double median split is then used to identify reflective learners, who are relatively slow but make few errors, and impulsive learners, who are relatively fast and make more errors. The two remaining categories are called fast accurate learners and slow inaccurate learners; learners in these categories do not nicely fit within the reflection-impulsivity dimension.

As another example, Sternberg, Grigorenko, Ferrari, and Clinkenbeard (1999) used the Sternberg Triarchic Abilities Test to measure learners' analytical, creative, and practical abilities. Learners for whom one of these abilities was much higher than the other two abilities were assigned to a highanalytical, high-creative, or high-practical style. In addition, learners who scored high on all three abilities were assigned to a high-balanced style and learners who scored low on all three abilities were assigned to a low-balanced style. Of the 326 students in their study, 199 students $(61 \%)$ could be assigned to one of the five groups on the basis of their pattern of ability-test scores. Results of the intervention study showed that, as predicted, students who were matched to instruction (i.e., high-analytical students received analytical instruction, high-creative students received creative 
instruction, and high-practical students received practical instruction) outperformed students who were not matched to instruction on three tests using analytical tasks, creative tasks, and practical tasks.

However, students with a high-balanced style were always included in the matched group, and students with a low-balanced style were always included in the unmatched group. As indicated by Sternberg et al. (1999) themselves, this may yield a confounding of the interaction effect with an effect of the $g$-factor (i.e., general intelligence). More important, we think it does not make sense to distinguish these high- and low-balanced styles because instruction cannot be aligned accordingly. When only the three groups with highanalytical, high-creative, and high-practical students were analyzed, students who were matched to instruction still outperformed students who were not matched to instruction on two of the three tests. This finding, however, is then based on only 112 of the original 326 students in the study (35\%). Thus, even when learning styles have implications for instruction, this is probably not true for the vast majority of students because they do not fit extreme groups. Furthermore, according to reviews of research on this issue, there are very few studies that find such crossover interactions and many more studies that do not find any interactions (Pashler, McDaniel, Rohrer, \& Bjork, 2008).

A second problem pertains to the information used to determine learners' learning styles. Almost without exception, self-report measures are used; however, the adequacy of such self-reports for the assessment of learning styles is questionable (see, e.g., Veenman, Prins, \& Verheij, 2003). People may not be able and/or willing to report on the styles they use to learn. Stahl (1999) reported low reliabilities for the measurement of learning styles; when individuals complete a particular measurement at two different points in time the results are very often inconsistent. For example, reliabilities for popular instruments such as Carbo's Reading Style Inventory, Dunn and Dunn's Learning Style Inventory, and the Myers-Briggs Type Inventory are in the neighborhood of the $.60 \mathrm{~s}$ and the $.70 \mathrm{~s}$, which is lower than one should expect from a diagnostic measure.

At least equally important is the validity of the learning styles measures: Do they really measure what they aim to measure? Again, the relationship between what people say about how they learn and how they actually learn is weak. For example, in a carefully designed study by Massa and Mayer (2006), the self-reported preference for visual versus verbal information intake had a very weak relationship with an individual's objectively measured abilities (i.e., spatial ability). The individually preferred way of learning is often a bad predictor of the way people learn most effectively; what people prefer is often not what is best for them. The implications for measurement are clear. When designing instruction that takes differences between learners into account, one should assess cognitive abilities rather than preferred learning styles because abilities are better predictors of how people learn most effectively. Moreover, these cognitive abilities should be objectively measured on an ordinal scale and in an objective way, rather than by subjective self-reports that are used to assign people to types on the basis of one or more arbitrary criteria.

The third and final problem with learning styles research is that the mere number of reported learning styles is problematic. In a review, Coffield et al. (2004) described 71 different learning styles. If we start from the conservative assumption that each learning style is dichotomous there would already be $2^{71}$ combinations of learning styles. This means that there are many more combinations of styles than people living on Earth. The truth might be that people are different from each other on so many style dimensions, and for each dimension in so many degrees, that it becomes totally impractical to take these differences into account in instruction, even if the previous two problems did not exist!

\section{Is What Learners Say They Prefer Good for Them?}

If we set all of the difficulties associated with the measurement of learning styles aside, the next question is how to tailor instruction to particular learning styles. This is where the learning-styles hypothesis (Pashler et al., 2008) comes into play. The required evidence for the learning-styles hypothesis is a crossover interaction in which type A learners learn better with instructional method $\mathrm{A}$, whereas type $\mathrm{B}$ learners learn better with instructional method B. For example, according to this hypothesis, verbal learners will learn best with verbal instructional methods (e.g., reading a book), whereas visual learners will learn best with visual instructional methods (e.g., watching a video). Here, it is important to note that a statistically significant interaction between learning style and instructional method is in itself not enough to have any practical educational meaning. van Merriënboer (1990), for example, compared two instructional methods for teaching computer programming: The generation method stressed the writing of programming code (matching an impulsive approach), whereas the completion method stressed the study and completion of existing programming code (matching a reflective approach). Although there was a tendency showing that reflective learners profited more from the completion strategy than impulsive learners, the completion strategy was still superior to the generation strategy for both types of learners. Thus, studies may show interactions between learning styles and instructional methods that have no practical educational implications; only crossover interactions provide acceptable evidence for the learning styles hypothesis.

In the learning styles literature, the theoretical basis for the formulation of crossover interactions is typically based on a preferential model, also called the meshing hypothesis (Pashler et al., 2008). The basic idea is that instruction should be provided in the mode that best matches the learner's style; thus, the learner is assumed to "know" what is best for him 
or her. As already indicated in the previous section, the preferred way of learning, however, does not need to be the most productive way of learning. Let us make a comparison with food. Suppose that we ask children what food they prefer. Some children might prefer fruit and milk, but the majority will prefer candy and soft drinks. Would this be a justified reason to give these children the food they prefer? We think not, simply because the preferred food will have a negative effect on their health. Similarly, Clark (1982) found in a meta-analysis of studies using learner preference for selecting particular instructional methods that learner preference was typically uncorrelated or negatively correlated to learning and learning outcomes. That is, learners who reported preferring a particular instructional technique typically did not derive any instructional benefit from experiencing it. Frequently, so-called mathemathantic (from the Latin mathema $=$ learning + thanatos $=$ death) effects are found, that is, teaching kills learning when instructional methods match a preferred but unproductive learning style (Clark, 1989). Giving children candy and soft drinks because they prefer them is an example of bad nutritional practice just as catering to unproductive learning styles is an example of bad educational practice. In such situations, a compensation model that makes up for the undesirable effects of a particular inclination or learning style would be more applicable than a preferential model (van Merriënboer, 1990).

Another complication that has, to our knowledge, not been discussed in the literature so far is that a learning style that might be desirable in one situation might be undesirable in another situation due to the multifaceted nature of complex skills. Suppose that one is teaching in the medical domain: One instructional method may emphasize learning-by-observation and matches - according to the preferential model - a reflective style, whereas the other instructional method may emphasize learning-by-doing and better matches an impulsive style. When medical diagnosis is taught, it is particularly important that learners base their decisions on all available information and systematically exclude alternative hypotheses before they reach a diagnosis; the preferred style for learning this particular complex skill is a reflective one. For teaching medical diagnosis, it thus makes sense to use learning-by-observation for reflective students, but it seems better not to teach impulsive students through learning-by-doing but rather to teach them to compensate for their counterproductive style. In contrast, when emergency care is taught, it is particularly important that learners can make decisions on the basis of incomplete information and give priority to speed over fastidiousness; the preferred style is an impulsive one. Consequently, for teaching emergency care, it makes sense to use learning-by-doing for impulsive students but it seems better not to teach reflective students through learning-by-observation but now to teach these students to compensate for their counterproductive style. The point is that simple two-way interactions between learning styles and instructional methods, based on either a preferen- tial model or a compensation model, do not take into account additional relevant factors such as the nature of the knowledge and skills that are taught or the context in which they are taught.

Given these complexities, it is particularly interesting to search the literature for studies that report crossover interactions between learning styles and instructional methods, irrespective of the question whether these interactions are based on a preferential model or a compensation model. Unfortunately, review studies indicate that the evidence for such interactions is almost completely absent (see Coffield et al., 2004; Pashler et al., 2008; Rohrer \& Pashler, 2012). Even exceptions such as the study by Sternberg et al. (1999) reported earlier provide less than compelling evidence because reported results are based on only a fraction of the participants. On the other side, several well-designed recent studies contradict the learning styles hypothesis. Constantinidou and Baker (2002), for example, found no relationship between a visual learning style and the actual learning of verbal items that were presented either visually or auditory. In a series of carefully designed experiments, Massa and Mayer (2006) also found no support for the idea that different instructional methods, emphasizing either pictorial or verbal information, should be used for visualizers and verbalizers. Similar negative findings are reported for other learning styles. In the medical domain, Cook, Thompson, Thomas, and Thomas (2009), for example, found no support for the idea that different instructional methods, working either from problems to theoretical information (inductive) or from theoretical information to problems (deductive), should be used for sensing/concrete learners and intuitive/abstract learners.

To summarize, the idea that learners with different learning styles should be taught with different instructional methods is a belief for which very little, if any, scientific evidence exists. There are fundamental problems with regard to the measurement of learning styles and the theoretical basis for the assumed interactions between learning styles and instructional methods, and, last but not least, substantial empirical evidence for the learning styles hypothesis is missing.

From an educational point of view, it is probably more fruitful to focus on the fundamental things that learners have in common (i.e., their cognitive architecture; Sweller, van Merriënboer, \& Paas, 1998; van Merriënboer \& Sweller, 2005) than on the myriad of styles on which they may be different from each other. A focus on what learners have in common does not deny that there are individual differences; rather, it helps to identify differences that really matter in education and to design instructional methods that are practically feasible. For example, there is scientific evidence that objectively measured cognitive abilities and, especially, prior knowledge should be taken into account when instructional methods are applied. The expertise-reversal effect (Kalyuaga, Ayers, Chandler, \& Sweller, 2003), for instance, indicates that learners with low prior knowledge learn more from studying examples than from solving the equivalent problems and that 
this pattern reverses for learners with higher prior knowledge. The point we want to make is that there is no scientific evidence whatsoever that learning styles provide a useful construct to base the selection of instructional methods on, not that instructional methods should never be sensitive for differences between learners. Despite decades of research, the field of learning styles has failed to make significant progress and so far it does not yield any valid educational implications.

In other words, though very appealing, there is no solid evidence that learning styles - as such — actually exist and that there is any benefit to adapting and designing education and instruction to these so-called styles. It may even be the case, that in doing so, administrators, teachers, parents, and even learners are negatively influencing the learning process and the products of education and instruction.

\section{LEARNERS AS SELF-EDUCATORS (ON THE INTERNET)}

A third legend has it that all that one needs to know and learn is "out there on the web" and that there is, thus, no need to teach and/or acquire such knowledge any more. This has led, for example, to the demotion of the teacher from someone whose job it was to combine her/his knowledge within a domain combined with her/his pedagogical content knowledge so as to teach those lacking this knowledge to someone whose role is standing on the sidelines and guiding and/or coaxing a breed of self-educators. These self-educators can self-regulate and self-direct their own learning, seeking, finding, and making use of all of the information sources that are freely available to them. In the following subsections, this final student urban legend is discussed.

\section{Seek and Ye Shall Find}

The premises underlying the idea of substituting information seeking for teaching is that the half-life of information is getting smaller every day, making knowledge rapidly obsolete, and because it is all out there on the web, we should not teach knowledge but should instead let kids look for it themselves. This has led to the Googlification of education, a watered-down version of resource-based learning (Hill \& Hannafin, 2001). Marcum (2003), for example, wrote,

The "half life" of information usefulness has shrunk from a century or a generation to perhaps no more than days or even hours in some fields, where anything in print is automatically deemed obsolete. Today the information underlying the first year of a certain technical degree can be half useless by graduation day. Currency now prevails. (p. 28)

The idea that the present body of knowledge is rapidly becoming out of date or obsolete is far from true. First, a distinction needs to be made with respect to the difference between knowledge obsolescence and information growth. It is indeed true that the last decades have seen an enormous growth in the amount of information available, primarily due to the simple and low-cost of the World Wide Web. This, however, does not mean that the knowledge that existed prior to the Internet revolution is obsolete, irrelevant, or no longer holds. The fact is that much of what has passed for knowledge in previous generations is still valid and useful. What is true is that there is an increasing amount of new information becoming available, some of it trustworthy, some not. To adequately deal with this stream of new information that increases in size and tempo daily, one must be able to search, find, evaluate, select, process, organize, and present information. However, as Hannafin and Hill (2007) warned, "while technology has been lauded for potentially democratizing access to information, educational use remains fraught with issues of literacy, misinterpretation, and propagandizing" (p. 526).

The set of activities and/or skills needed to adequately deal with this information generation and dissemination is frequently referred to as information literacy or-when information and communication technologies also play a key role — digital literacy activities/skills (Bawden, 2001; BrandGruwel \& Gerjets, 2008; Brand-Gruwel, Wopereis, \& Walraven, 2009; Eisenberg \& Berkowitz, 1990; Jones-Kavalier \& Flannigan, 2006; Moore, 1995; Wolf, Brush, \& Saye, 2003). This is often seen as one of the core 21st-century skills propagated in much school policy (Anderman, Sinatra, \& Gray, 2012; Dede, 2010; European Commission, 2002; Voogt \& Pareja Roblin, 2010).

Although students are often thought of as being competent or even expert in information problem solving (i.e., that they are information and digitally literate) because they are seen searching the web daily, research reveals that solving information problems is for most students a major if not insurmountable cognitive endeavor. Searching, finding, and processing information is a complex cognitive process that requires identifying information needs, locating corresponding information sources, extracting and organizing relevant information from each source, and synthesizing information from a variety of sources. According to Miller and Bartlett (2012), effective Internet use requires distinguishing good information from bad. They noted, however, that learners are not astute Internet users. Learners not only have problems finding the information that they are seeking but also often trust the first thing they see, making them prone to "the pitfalls of ignorance, falsehoods, cons and scams" (p. 35). Many researchers (e.g., Bilal, 2000; Large \& Beheshti, 2000; MaKinster, Beghetto, \& Plucker, 2002; Wallace, Kupperman, Krajcik, \& Soloway, 2000) have demonstrated that young children, teenagers, and adults are not capable of effectively choosing proper search terms, selecting the most relevant websites, and questioning the validity of sources. Furthermore, research of Brand-Gruwel, Wopereis, and Vermetten (2005); Branch (2001); Gross and Latham (2007); and Lazonder (2000) revealed that students lack regulatory skills and have difficulties defining the information problem; 
identifying what they do not know. Taking all of these research results into account, it can be concluded that students must learn to solve information-based problems and must learn transferable search and evaluation strategies.

This leads to the second premise behind the recommendation to allow students to learn from the Internet - namely, that because it is all on the web, there is no need to teach it. Indeed, much, if not all of the "knowledge" that is to be gained in school is on the web. However, as Kirschner $(1992,2009)$ previously wrote, it is what one already knows that determines what one sees and understands and not the other way around. Thus, prior knowledge largely determines how we search, find, select, and process (i.e., evaluate) information found on the web. Students often receive assignments containing an information problem and are expected to search for the information needed to solve that problem and construct new knowledge. Unfortunately, in most cases students' prior knowledge of the subject matter is minimal. From research, it is known that low prior knowledge negatively influences the search process (Fidel et al., 1999; Hirsch, 1999). For example, Nievelstein (2009; Nievelstein, Van Gog, Boshuizen, \& Prins, 2008) found that 1 st- and 3rd-year law students experienced great difficulties using sources such as law books and court judgments due to a lack of the conceptual and ontological knowledge necessary to interpret the information found in the source. Students with more prior knowledge have an advantage because they can easily link their prior knowledge to the task requirements and to information found on the web.

The fact that students make use of many electronic devices and are called digital natives, does not make them good users of the media that they have at their disposal. They can Google but lack the information skills to effectively find the information they need, and they also do not have the knowledge to adequately determine the relevance or truth of what they have found (Walraven, Brand-Gruwel, \& Boshuizen, 2008). This leads to essays on Baconian science with texts about the 20th-century British artist Francis Bacon and on the problems that Martin Luther King had with Pope Leo X and Holy Roman Emperor Charles V. It also leads to prospective presidential candidates mistaking the birthplace of John Wayne (the actor) with John Wayne Gacy (the murderer convicted of killing more than 30 young men in the 1970s [Oliphant, 2011])!

\section{The Learner in Control}

Western society has changed. We have moved away from a society in which authority is accepted and even appreciated into one where it is questioned and where we feel that we are best at determining what we do and how we should do it; we are a society of knowledgeable and articulate consumers of goods and services. In this society, students are expected to act independently, take responsibility for their learning process and regulate their own school behavior (Veugelers, 2004). Self-direction, self-determination, and choice are key concepts. Schools are expected to design education that enhances and complements students' self-regulated learning (Van Hout-Wolters, Somons, \& Volet, 2000) where teachers give students the opportunity to practice self-regulated learning. On some accounts, student-directed education is to replace teacher-directed education (Gibbons, 2002). Hase and Kenyon (2000) called this the shift from andragogy (i.e., focusing on the best ways for people to learn) to heutagogy (i.e., focusing on learning how to learn and learner self-direction). In this society, the doctor is no longer the authority but someone who you go to for a second opinion; the first opinion being that which you yourself determined by Googling your symptoms. Newspapers and journalists are no longer the main source of current events information but rather blogs, websites, tweets, and aggregators where anyone can post anything she or he wishes. And because this is the trend in current society, the thinking is that we should use self-directed and self-determined learning in education. But, as shown earlier in this article, learners neither are skilled in information problem solving (i.e., they are not really information literate) nor have the expertise needed to determine what they do not know and what they, therefore, need to learn. This leads to three problems.

The first problem relates to placing the locus of control with the learner. According to Lee, Lim, and Grabowski (2010), learners are not always successful controlling their own learning, especially in computer-based learning environments. There is a large body of research (see M. D. Williams, 1996, for an excellent review) which shows that not all learners prefer nor profit from controlling the tasks (Carrier, 1984; Milheim \& Martin, 1991) and that forcing such control on them can be counterproductive (Rasmussen \& Davidson-Shivers, 1998). Merrill (1984), for example, concluded that college-level students generally do not make good use of learner control options, a position also taken by Carrier (1984). The reason for this is that learners do not have or do not know how to utilize appropriate strategies when they are left to themselves to manage their learning environment (i.e., they do not have the capacity to appraise both the demands of the task and their own learning needs in relation to that task in order to select appropriate instruction). In other words, learners often misregulate their learning, exerting control in a misguided or counterproductive fashion and not achieving the desired result. This is due to (a) not having the necessary standards upon which to judge their learning state, (b) not having the necessary knowledge to monitor their own state in comparison with the standards, and/or (c) not being able to initiate the proper processes to change their current state when their behavior falls short of the standards (Baumeister \& Heatherton, 1996; Taminiau et al., 2013).

The second problem is that learners often choose what they prefer, but what they prefer is not always what is best for them. The current obesity pandemic is probably the best proof of this! One type of mathemathantic behavior (Clark, 
1989) occurs when learner control is substituted for system control over contents (e.g., by allowing difficult or unfamiliar contents to be chosen by students with high fear of failure) or instructional methods (e.g., by allowing lower cognitive load instructional methods to be chosen by high general ability, constructive students). For example, Kicken, Brand-Gruwel, van Merriënboer, and Slot (2009) found that giving low general ability students in the hairdressing domain full learner control created a situation in which they continued to practice tasks they liked or were already proficient in (e.g., washing hair) but the students were reluctant to start with new, yet unfamiliar tasks (e.g., permanent waving). Providing the students with an electronic development portfolio, which allows them to monitor their progress on all relevant hairdressing skills, helps them to make better task selections, but only when the use of the portfolio is combined with regular coaching meetings and explicit advice from the teacher (Kicken, Brand-Gruwel, \& van Merriënboer, 2009).

A final problem is known as the paradox of choice. People appreciate having the opportunity to make some choices, but the more options that they have to choose from, the more frustrating it is to make the choice (Schwartz, 2004). It is, thus, important to give learners limited rather than unlimited control, because having to choose from too many options is perceived as frustrating. Corbalan, Kester, and van Merriënboer (2006) described shared control as a promising way to reach this goal. Shared control is a two-step process, in which the teacher or coach first selects from all available learning tasks a subset of tasks with characteristics that fit the needs of the learner. This should prevent overwhelming and frustrating the learner by letting him or her choose from a very large set of tasks. Second, the learner selects from this subset one task to work on. With learning tasks in the dietetics domain, shared control had superior effects on student motivation (Corbalan, Kester, \& van Merriënboer, 2008). With learning tasks in the genetics domain, shared control over task selection had superior effects on both student motivation and learning, provided that learners had to choose from a subset of preselected tasks with features that were different from the features of previous tasks (Corbalan, Kester, \& van Merriënboer, 2009). van Merriënboer and Kirschner (2013) referred to this approach as second-order scaffolding, in which there is gradually decreasing support and guidance for self-directed learning skills. This second-order scaffolding helps learners learn to select learning tasks, find relevant supportive information, consult necessary procedural information, and identify useful part-task practice. The instruction shifts gradually from traditional teacher or system controlled learning environments, in which a teacher or another intelligent agent assesses a learner's performance and selects suitable further learning tasks, to on-demand education, in which the learner self-assesses her or his performance and independently selects her or his own learning tasks.

Our recommendation, then, is to appropriately limit students' control in consideration of their developmental level.
Providing some autonomy - but not too much - appears to us to be broadly consistent with the motivation research that advocates granting autonomy to students (Stefanou, Perencivich, Dicintio, \& Turner, 2004).

\section{CONCLUSIONS}

Our analysis of three urban legends in teaching and education clearly shows that, although widespread, widely believed, and even widely implemented as well-meaning educational techniques or innovations, they are not supported by scientific evidence. It should be clear by now that students are really not the best managers of their own learning with respect to navigating through and learning in the digital world, choosing the best way in which to study and learn (i.e., learning styles), or gathering useful information from the Internet. However, a continuum of available evidence exists for refuting these and other legends. At one extreme, are urban legends for which there is a tiny bit of incomplete support-but the legend itself is false or at least a severe overgeneralization (e.g., the claim that giving learners full control over the learning process will have positive effects on learning). At the other extreme of the continuum are urban legends for which there is strong empirical evidence for the opposite, showing that they are totally counterproductive in education (e.g., the claim that children are capable of effective multitasking). Finally, there are urban legends for which researchers claim that there is evidence, and for which there are even empirical studies purporting to support the legend, but the research itself or the body of research is flawed. This was demonstrated for the learning styles hypothesis but also, for example, by Lalley and Miller (2007) with respect to the learning pyramid and by Kirschner, Sweller, and Clark (2006) with respect to minimal guidance during instruction. It is yet true for all legends that they are primarily based on beliefs and convictions, not on scientific theories supported by empirical findings.

The major point here is that educators, educational policymakers and educational researchers should reject educational approaches that lack sufficient scientific support and methodologically sound empirical evidence. The degree of support an educational intervention needs before it is widely adopted is what is important. In the $1960 \mathrm{~s}$, '70s, and ' $80 \mathrm{~s}$, much research was carried out on how learning could be positively influenced by influencing how the learner studied and, thus, processed the learning materials. Examples of such research and the design principles flowing from them are as follows:

- Adjunct questions and mathemagenic behaviors (Rothkopf, 1970): Inserting questions prior to or after text passages which give birth to learning and learning activities.

- Advance organizers and meaningful verbal learning (Ausubel, 1960): Information preceding a learning episode at a higher level of abstraction, generality, 
and inclusiveness that subsumes new-to-be-learnedinformation.

- Elaboration theory (Reigeluth, Merrill, Wilson, \& Spiller, 1980; Reigeluth \& Stein, 1983): Organizing to-be-learned content from simple to complex so that a meaningful context is created to integrate subsequent ideas.

- Text structure (Jonassen \& Kirschner, 1982): Using headings, structuring principles (e.g., thematic, topical), outlines and schemas, and so on, to prestructure texts for better learning.

Based on solid empirical research, textbooks were produced according to instructional design approaches found in works as Principles of Instructional Design (Gagné \& Briggs, 1979), through Instructional Design Theory (Merrill, 1994) and Four Component Instructional Design (van Merriënboer, 1997) up to Ten Steps To Complex Learning (van Merriënboer \& Kirschner, 2013). This evolution in instructional design is evidence based in that it uses solid empirical evidence up to and including new insights from research-based theories in the field of learning and instruction.

What we are dealing with here is a very popular and very persistent pseudoscience, which jeopardizes both the quality of education and the credibility of the educational sciences. There is the risk that we are entering a downward spiral: The popularity of urban legends paints the educational sciences as a mumbo-jumbo science, which in turn makes it increasingly difficult to move valuable innovations in the field of education into practice. How can we avoid this downward spiral? In our view, there is only one way to go: The educational sciences must be driven by theories and theory development based on empirical data rather than legends, hypes, and methodologically unsound research (e.g., Homo Zappiens, Web 2.0, brain-based teaching).

Research should not simply try to find out "what works" (cf. Chatterji, 2005; Olsen, 2004) but should be aimed at explaining why particular methods help and why others do not help to reach particular goals in particular types of education under particular conditions. There are no "single methods" in education, or in any other complex human system, which work well for all goals under all conditions (Atkinson, 2000; Berliner, 2002; van Merriënboer \& Kirschner, 2007, 2013). The enormous complexity of the field of education should be reflected in its theories, and the construction of such theories is a long-term endeavor, based on programmed research and the work of many collaborating researchers and practitioners, using a broad variety of research methods ranging from qualitative, explorative studies to large-scale, randomized controlled trials. The step from legend-based education based on pseudoscience to evidence-based education based on science demands a quantum leap. Rather than a quick change in research methodologies or objects of study, it requires a fundamental change in scientific attitude.
This, however, will not be easy. Bennett et al. (2008), in reviewing the literature on digital natives, for example, wrote of an academic form of moral panic. According to Cohen (1973), moral panic occurs when a "condition, episode, person or group of persons emerges to become defined as a threat to societal values and interests" (p. 9). In their article they describe why such legends catch on so easily and why they are so persistent/hard to eradicate. In essence,

\begin{abstract}
Arguments are often couched in dramatic language, proclaim a profound change in the world, and pronounce stark generational differences...

Such claims coupled with appeals to common sense and recognizable anecdotes are used to declare an emergency situation, and call for urgent and fundamental change.

Another feature of this "academic moral panic" is its structure as a series of strongly bounded divides: between a new generation and all previous generations; between the technically adept and those who are not; and between learners and teachers. ...

Thus, the language of moral panic and the divides established by commentators serve to close down debate, and in doing so allow unevidenced claims to proliferate. (pp. 782-783)
\end{abstract}

McRobbie and Thornton (1995) concluded in their study of the persistence of moral panic that (a) the object of the panic (here the problems with education) receives free publicity because the supposed negative associations make it newsworthy and (b) rather than alienating everyone, it becomes attractive to those who see themselves as alternative and avant-garde. Noymer (2001), studying the transmission and persistence of urban legends, confirmed a nonlinear model of urban legends in which

the most rapid path to endemicity (persistence) occurs when skeptics play an active role in trying to suppress a rumor, a process I label "autocatalysis." This is counterintuitive, since autocatalysis of skepticism should suppress rumors. ... When skeptics try to stop a rumor from spreading further, the nature of the dynamics changes from epidemic cycles to endemic transmission; skeptics actions are at cross-purposes to their intentions. (pp. 320-321)

In other words, the beliefs that a person holds persist in the face of data that disproves or even contradicts those beliefs (C. A. Anderson \& Kellam, 1992). With this in mind, this article may achieve the opposite of its intention!

\section{REFERENCES}

Anderman, E. M., Sinatra, G., \& Gray, D. (2012). The challenges of teaching and learning about science in the 21 st century: Exploring the abilities and constraints of adolescent learners. Studies in Science Education, 48, 89-117.

Anderson, C. A., \& Kellam, K. L. (1992). Belief perseverance, biased assimilation, and covariation detection: The effects of hypothetical social 
theories and new data. Personality and Social Psychology Bulletin, 18, 555-565. doi:10.1177/0146167292185005

Anderson, S. (2009). In defense of distraction. New York Magazine, 42(18), 28-101. Retrieved from http://nymag.com/news/features/56793/

Atkinson, E. (2000). In defense of ideas, or why "what works" is not enough. Management in Education, 14(3), 6-9.

Ausubel, D. (1960). The use of advance organizers in the learning and retention of meaningful verbal material. Journal of Educational Psychology, $51,267-272$

Baumeister, R. F., \& Heatherton, T. F. (1996). Self-regulation failure: An overview. Psychological Inquiry, 7, 1-15. doi:10.1207/s15327965pli0701_1

Bawden, D. (2001). Information and digital literacies: A review of concepts. Journal of Documentation, 57, 218-259. doi:10.1108/EUM0000000007083

Bennett, S., Maton, K., \& Kervin, L. (2008). The "digital natives" debate: A critical review of the evidence. British Journal of Educational Technology, 39, 775-786. doi:10.1111/j.1467-8535.2007.00793.x

Berliner, D. C. (2002). Educational research: The hardest science of all. Educational Researcher, 31(8), 18-20. doi:10.3102/0013189X031008018

Beyler, J., \& Schmeck, R. R. (1992). Assessment of individual differences in preferences for holistic-analytic strategies: Evaluation of some commonly available instruments. Educational and Psychological Measurement, 52, 709-719. doi:10.1177/0013164492052003021

Bilal, D. (2000). Children's use of the Yahooligans! Web search engine: I. Cognitive, physical, and affective behaviors on fact-based search tasks. Journal of the American Society of Information Science, 51, 646-665. doi:10.1002/(SICI)1097-4571(2000)51:7

Branch, J. L. (2001). Junior high students and think alouds: Generating information-seeking process data using concurrent verbal protocols. Library \& Information Science Research, 23, 107-122. doi:10.1016/ S0740-8188(01)00065-2

Brand-Gruwel, S., \& Gerjets, P. (2008). Instructional support for enhancing students' information problem solving ability. Computers in Human Behavior, 24, 615-622. doi:10.1016/j.chb.2007.01.020

Brand-Gruwel, S., Wopereis, I., \& Vermetten, Y. (2005). Information problem solving by experts and novices: Analysis of a complex cognitive skill. Computers in Human Behavior, 21, 487-508. doi:10.1016/j.chb.2004.10.005

Brand-Gruwel, S., Wopereis, I., \& Walraven, A. (2009). A descriptive model of information problem solving while using Internet. Computers \& Education, 52, 1207-1217. doi:10.1016/j.compedu.2009.06.004

Brumby, D. P., \& Salvucci, D. D. (2006). Exploring human multitasking strategies from a cognitive constraint approach. In Proceedings of the 28th Annual Conference of the Cognitive Science Society (p. 2451). Mahwah, NJ: Erlbaum.

Brumby, D. P., Salvucci, D. D., \& Howes, A. (2009). Focus on driving: How cognitive constraints shape the adaptation of strategy when dialing while driving. In Proceedings of the SIGCHI Conference on Human Factors in Computing Systems, CHI'09 (pp. 1629-1638). New York, NY: ACM.

Bullen, M., Morgan, T., Belfer, K., \& Qayyum, A. (2008, October). The digital learner at BCIT and implications for an e-strategy. Paper presented at the 2008 Research Workshop of the European Distance Education Network (EDEN), Paris, France.

Carrier, C. (1984). Do learners make good choices? Instructional Innovator, 29(2), 15-17.

Cassidy, S. (2004). Learning styles: An overview of theories, models, and measures. Educational Psychology, 24, 419-444. doi:10.1080/ 0144341042000228834

Chatterji, M. (2005). Evidence on "what works": An argument for extended-term mixed-method (ETMM) evaluation designs. Educational Researcher, 34(5), 14-24. doi:10.3102/0013189X033009003

Clark, R. E. (1982) Antagonism between achievement and enjoyment in ATI studies. Educational Psychologist, 17, 92-101.
Clark, R. E. (1989). When teaching kills learning: Research on mathemathantics. In H. N. Mandl, N. Bennett, E. de Corte, \& H. F. Friedrich (Eds.), Learning and instruction: European research in an international context (Vol. 2, pp. 1-22). London, UK: Pergamon.

Coffield, F., Moseley, D., Hall, E., \& Ecclestone, K. (2004). Learning styles and pedagogy in post-16 learning: A systematic and critical review. London, UK: Learning and Skills Research Centre.

Cohen, S. (1973). Folk devils and moral panics. St Albans, UK: Paladin.

Coiera, E., Jayasuria, R. A., Hardy, J., Bannan, A., \& Thorpe, M. (2002). Communication loads on clinical staff in the emergency department. Medical Journal of Australia, 176, 415-418.

Constantidinou, F., \& Baker, S. (2002). Stimulus modality and verbal learning performance in normal aging. Brain and Language, 82, 296-311. doi:10.1016/S0093-934X(02)00018-4

Cook, D. A., Thompson, W. G., Thomas, K. G., \& Thomas, M. R. (2009). Lack of interaction between sensing-intuitive learning styles and problemfirst versus information-first instruction: A randomized cross-over trial. Advances in Health Sciences Education, 14, 79-90. doi:10.1007/s10459007-9089-8

Corbalan, G., Kester, L., \& van Merriënboer, J. J. G. (2006). Towards a personalized task selection model with shared instructional control. Instructional Science, 34, 399-422. doi:10.1007/s11251-0055774-2

Corbalan, G., Kester, L., \& van Merriënboer, J. J. G. (2008). Selecting learning tasks: Effects of adaptation and shared control on learning efficiency and task involvement. Contemporary Educational Psychology, 33, 733-756. doi:10.1016/j.cedpsych.2008.02.003

Corbalan, G., Kester, L., \& van Merriënboer, J. J. G. (2009). Combining shared control with variability over surface features: Effects on transfer test performance and task involvement. Computers in Human Behavior, 25, 290-298. doi:10.1016/j.chb.2008.12.009

Dede, C. (2010). Comparing frameworks for 21 st century skills. In J. Bellanca \& R. Brandt (Eds.), 21st century skills (pp. 51-76). Bloomington, IN: Solution Tree Press.

Dismukes, K., Young, G., \& Sumwalt, R. (1998). Cockpit interruptions and distractions: effective management requires a careful balancing act. ASRS (Aviation Safety Reporting System) Directline, 10, 4-9.

Druckman, D., \& Porter, L. W. (1991). Developing careers. In D. Druckman $\&$ R. A. Bjork (Eds.), In the mind's eye: Enhancing human performance (pp. 80-103). Washington, DC: National Academy Press.

Dux, P. E., Ivanoff, J., Asplund, C. L., \& Marois, R. (2006). Isolation of a central bottleneck of information processing with time-resolved fMRI. Neuron, 52, 1109-1120. doi :10.1016/j.neuron.2006.11.009

Ebner, M., Schiefner, M., \& Nagler, W. (2008). Has the Net-Generation arrived at the university? - oder der Student von Heute, ein Digital Native? [or Contemporary student-a Digital Native?]. In S. Zauchner, P. Baumgartner, E. Blaschitz, \& A. Weissenbäck (Eds.), Medien in der Wissenschaft (Vol. 48; pp. 113-123). Muenster, Germany: Waxmann Verlag. doi:10.1016/j.ijmedinf.2006.09.019

Eisenberg, M. B., \& Berkowitz, R. E. (1990). Information problem-solving: The big six skills approach to library and information skills instruction. Norwood, NJ: Ablex.

European Commission. (2002). eEurope 2005: An information society for all. Brussels, Belgium: European Commission.

Fidel, R., Davies, R. K., Douglass, M. H., Holder, J. K., Hopkins, C. J., Kushner, E. J., ... Toney, C. D. (1999). A visit to the information mall: Web searching behavior of high school students. Journal of the American Society of Information Science, 50(1), 24-37. doi:10.1002/(SICI)10974571

Fox, A. B., Rosen, J., \& Crawford, M. (2009). Distractions, distractions: Does instant messaging affect college students' performance on a concurrent reading comprehension task? Cyberpsychology and Behavior, 12, 51-53. doi:10.1089/cpb.2008.0107

Gagné, R., \& Briggs, L. (1979). Principles of instructional design (2nd ed.). New York, NY: Holt, Rinehart, and Winston. 
Gibbons, M. (2002). The self-directed learning handbook: Challenging adolescent students to excel. San Francisco, CA: Jossey-Bass.

Gladstone, J. (1995). Drug administration errors: A study into the factors underlying the occurrence and reporting of drug errors in a district general hospital. Journal of Advanced Nursing, 22, 628-637. doi:10.1046/j.13652648.1995.22040628.x

Gross, M., \& Latham, D. (2007). Attaining information literacy: An investigation of the relationship between skill level, self-estimates of skill, and library anxiety. Library Information Science Research, 29, 332-353. doi:10.1016/j.lisr.2007.04.012

Hannafin, M. J., \& Hill, J. (2007). Resource-based learning. In M. Spector, M. D. Merrill, J. van Merrienboer, \& M. P. Driscoll (Eds.), Handbook of research on educational communications and technology (3rd ed., pp. 525-536). Mahwah, NJ: Erlbaum.

Harp, S. F., \& Mayer, R. E. (1997). The role of interest in learning from scientific text and illustrations: On the distinction between emotional interest and cognitive interest. Journal of Educational Psychology, 89, 92-102. doi:10.1037/0022-0663.89.1.92

Hase, S., \& Kenyon, C. (2000). From andragogy to heutagogy. ultiBASE, 5(3). Retrieved from http://www.psy.gla.ac.uk/ steve/pr/Heutagogy.html Herman, T., Mirelman, A., Giladi, N., Schweiger, A., \& Hausdorff, J. M. (2011). Executive control deficits as a prodome to falls in healthy older adults: A prospective study linking thinking, walking, and falling. Journals of Gerontology. Series A, Biological Sciences and Medical Sciences, 65, 1086-1092. doi:10.1093/gerona/glq077

Hill, J. R., \& Hannafin, M. J. (2001). Teaching and learning in digital environments: The resurgence of resource-based learning. Educational Technology, Research and Development, 49(3), 37-52. doi:10.1007/BF02504914

Hirsch, S. G. (1999). Children's relevance criteria and information seeking on electronic resources. Journal of the American Society for Information Science, 50, 1265-1283. doi:10.1002/(SICI)1097-4571

Janssen, C. P., Brumby, D. P., Dowell, J., \& Chater, N. (2010). A cognitively bounded rational analysis model of dual-task performance trade-offs. In Proceedings of the 10th International Conference on Cognitive Modeling (pp. 103-108). Philadelphia, PA: Drexel University.

Jonassen, D., \& Kirschner, P. A. (1982). Explicit techniques for structuring text. In D. Jonasson (Ed.), The technology of text: Principles for structuring, designing, and displaying text (pp. 123-136). Englewood Cliffs, NJ: Educational Technology Publications.

Jones-Kavalier, B. R., \& Flannigan, S. L. (2006). Connecting the digital dots: Literacy of the 21st century. Educause Quarterly, 2, 8-10. Retrieved from http://www.educause.edu/ir/library/pdf/eqm0621.pdf

Kagan, J. (1965). Impulsive and reflective children: Significance of conceptual tempo. In J. Krumboltz (Ed.), Learning and the educational process (pp. 133-161). Chicago, IL: Rand McNally.

Kagan, J., Rosman, B. L., Day, D., Albert, J., \& Phillips, W. (1964). Information processing in the child: Significance of analytic and reflective attitudes. Psychological Monographs, 78 (1, Whole No. 578).

Kalyuga, S., Ayers, P., Chandler, P., \& Sweller, J. (2003). The expertise reversal effect. Educational Psychologist, 38, 23-32. doi:10.1207/ S15326985EP3801_4

Kennedy, G., Dalgarno, B., Gray, K., Judd, T., Waycott, J., Bennett, S., ... Churchward, A. (2007). The net generation are not big users of Web 2.0 technologies: Preliminary findings. In R. J. Atkinson, C. McBeath, S. K. A. Soong, \& C. Cheers (Eds.), ICT: Providing choices for learners and learning. Proceedings of ASCILITE 2007 Conference [Online]. Centre for Educational Development, Nanyang Technological University, Singapore. Retrieved from http://www.ascilite. org.au/conferences/singapore $07 /$ procs/kennedy.pdf

Kicken, W., Brand-Gruwel, S., \& van Merriënboer, J. J. G. (2009). The effects of portfolio-based advice on the development of self-directed learning skills in secondary vocational education. Educational Technology, Research and Development, 57, 439-460. doi:10.1007/s11423-009-9111-3

Kicken, W., Brand-Gruwel, S., van Merriënboer, J. J. G., \& Slot, W. (2009). Design and evaluation of a development portfolio: How to improve students' self-directed learning skills. Instructional Science, 37, 453-473. doi: $10.1007 / \mathrm{s} 11251-008-9058-5$
Kirschner, P. A. (1992). Epistemology, practical work, and academic skills in science education. Science and Education, 1, 273-299. doi:10.1007/BF00430277

Kirschner, P. A. (2009). Epistemology or pedagogy, that is the question. In S. Tobias \& T. M. Duffy (Eds.), Constructivist instruction: Success or failure? (pp. 144-157). New York, NY: Routledge.

Kirschner, P. A., Sweller, J., \& Clark, R. E. (2006). Why minimal guidance during instruction does not work: An analysis of the failure of constructivist, discovery, problem-based, experiential, and inquiry-based teaching. Educational Psychologist, 46, 75-86. doi:10.1207/s15326985ep4102_1

Kvavik, R. (2005). Convenience, communications, and control: How students use technology. In D. Oblinger \& J. Oblinger (Eds.), Educating the Net Generation (Chapter 7) [e-book]. Retrieved from http://www. educause.edu/educatingthenetgen/5989

Lalley, J. P., \& Miller, R. H. (2007): The learning pyramid: Does it point teachers in the right direction? Education, 128(1), 64-80.

Large, A., \& Beheshti, J. (2000). The web as a classroom resource: Reaction from the users. Journal of the American Society of Information Science, $51,1069-1080$.

Laxmisan, A., Hakimzada, F., Sayan, O. R., Green, R. A., Zhang, J., \& Patel, V. L. (2007). The multitasking clinician: Decision-making and cognitive demand during and after team handoffs in emergency care. International Journal of Medical Informatics, 76, 801-811. doi:10.1016/j.ijmedinf.2006.09.019

Lazonder, A. W. (2000). Exploring novice users' training needs in searching information on the WWW. Journal of Computer Assisted Learning, 16, 326-335. doi:10.1046/j.1365-2729.2000.00145.x

Lee, H. W., Lim, K. Y., \& Grabowski, B. L. (2010). Improving self-regulation, learning strategy use, and achievement with metacognitive feedback. Educational Technology Research and Development, 58, 629-648.

Lin, J. (2008, October 19). Research shows that Internet is rewiring our brains. UCLA Today. Retrieved from http://www.today.ucla.edu/portal/ ut/081015_gary-small-ibrain.aspx

MaKinster, J. G., Beghetto, R. A., \& Plucker, J. A. (2002). Why can't I find Newton's third law? Case studies of students' use of the web as a science resource. Journal of Science Education and Technology, 11, 155-172. doi:10.1023/A:1014617530297

Marcum, J. (2003, Fall/Winter). The 21st century library. FDU Magazine, $11(2), 26-29$.

Margaryan, A., Littlejohn, A., \& Vojt, G. (2011). Are digital natives a myth or reality? University students' use of digital technologies. Computers and Education, 56, 429-440. doi:10.1016/j.compedu.2010.09.004

Massa, L. J., \& Mayer, R. E. (2006). Testing the ATI hypothesis: Should multimedia instructions accommodate verbalizer-visualizer cognitive style? Learning and Individual Differences, 16, 321-336. doi:10.1016/j.lindif.2006.10.001

Mayer, R. E. (2005). The Cambridge handbook of multimedia learning. Cambridge, UK: Cambridge University Press.

McRobbie, A., \& Thornton, S. L. (1995). Rethinking "moral panic" for multi-mediated social worlds. The British Journal of Sociology, 46, 559-574. doi:10.2307/591571

Merrill, M. D. (1984). What is learner control? In R. Bass \& C. R. Dills (Eds.), Instructional development: The state of the art II (pp. 221-242). Dubuque, IA: Kendall/Hunt.

Merrill, M. D. (1994). Instructional design theory. Englewood Cliffs, NJ: Educational Technology Publications.

Messer, S. B. (1976). Reflection-impulsivity: A review. Psychological Bulletin, 83, 1026-1052. doi:10.1037/0033-2909.83.6.1026

Milheim, W. D., \& Martin, B. L. (1991). Theoretical bases for the use of learner control: Three different perspectives. Journal of Computer-Based Instruction, 18, 99-105.

Miller, C., \& Bartlett, J. (2012). 'Digital fluency': Towards young people's critical use of the internet. Journal of Information Literacy, 6(2), $35-55$.

Moore, P. (1995). Information problem solving: A wider view of library skills. Contemporary Educational Psychology, 20, 1-31. doi:10.1006/ ceps. 1995.1001 
Nievelstein, F. E. R. M. (2009) Learning law (Unpublished doctoral dissertation). Heerlen, The Netherlands: Open University of The Netherlands.

Nievelstein, F., Van Gog, T., Boshuizen, H. P. A., \& Prins, F. J. (2008). Expertise-related differences in conceptual and ontological knowledge in the legal domain. European Journal of Cognitive Psychology, 20, 1043-1064. doi:10.1080/09541440701674777

Noymer, A. (2001). The transmission and persistence of "urban legends": Sociological application of age-structured epidemic models. The Journal of Mathematical Sociology, 25, 299-323. Retrieved from http://www.escholarship.org/uc/item/0rv3c82q

Oblinger, D., \& Oblinger, J. (Eds.). (2005). Educating the Net Generation [e-book]. Retrieved from http://www.educause.edu/educatingthenetgen/5989

Oliphant, J. (2011, June 27). Michele Bachmann: Right town, wrong John Wayne. Los Angeles Times. Retrieved from http://articles.latimes.com/ 2011/jun/27/news/la-pn-bachmann-wayne-20110627

Olsen, D. R. (2004). The triumph of hope over experience in the search for "what works": A response to Slavin. Educational Researcher, 33, 24-26. doi:10.3102/0013189X033001024

Ophir, E., Nass, C. I., \& Wagner, A. D. (2009). Cognitive control in media multitaskers. Proceedings of the National Academy of Science of the United States of America, 106, 15583-15587. doi:10.1073/pnas.0903620106

Pashler, H., McDaniel, M., Rohrer, D., \& Bjork, R. (2008). Learning styles: Concepts and evidence. Psychological Science in the Public Interest, 9, 105-119. doi:10.1111/j.1539-6053.2009.01038.x

Peterson, G. M., Wu, M. S., \& Bergin, J. K. (1999). Pharmacist's attitudes towards dispensing errors: Their causes and prevention. Journal of Clinical Pharmacy and Therapeutics, 24, 57-71. doi:10.1046/j.13652710.1999.00199.x

Prensky, M. (2001). Digital natives, digital immigrants. On the Horizon, 9(5), 1-6.

Prensky, M. (2006). Listen to the natives Educational Leadership, 63(4), 8-13.

Rasmussen, K. L., \& Davidson-Shivers, G. V. (1998). Hypermedia and learning styles: Can performance be influenced? Journal of Educational Multimedia and Hypermedia, 7, 291-308.

Reigeluth, C., Merrill, M. D., Wilson, B., \& Spiller, R. (1980). The elaboration theory of instruction: A model for structuring instruction. Instructional Science, 9, 195-219.

Reigeluth, C. M., \& Stein, F. (1983). The elaboration theory of instruction. In C. M. Reigeluth (Ed.), Instructional design theories and models (pp. 335-381). Hillsdale, NJ: Erlbaum.

Richardson, A. (1977). Verbalizer-visualizer: A cognitive style dimension. Journal of Mental Imagery, 1, 109-126.

Rogers, R., \& Monsell, S. (1995). The costs of a predictable switch between simple cognitive tasks. Journal of Experimental Psychology: General, 124, 207-231.

Rohrer, D., \& Pashler, H. (2012). Learning styles: Where's the evidence? Medical Education, 46, 630-635.

Rosen, L. D. (2007). Me, MySpace, and I: Parenting the net generation. New York, NY: Palgrave Macmillan.

Rosen, L. D. (2009, April). Welcome to the iGeneration. Paper presented in the symposium "The iGeneration: Media Use, Health, and English Literacy," Western Psychological Association Convention, Portland, OR.

Rothkopf, E. Z. (1970). The concept of mathemagenic activities. Review of Educational Research, 40, 325-336.

Rowlands, I., Nicholas, D., Williams, P., Huntington, P., Fieldhouse, M., Gunter, B., ... Tenopir, C. (2008). The Google generation: The information behaviour of the researcher of the future. Aslib Proceedings: New Information Perspectives, 60, 290-310. doi:10.1108/00012530810887953

Rubinstein, J. S., Meyer, D. E., \& Evans, J. E. (2001). Executive control of cognitive processes in task switching. Journal of Experimental Psychology: Human Perception and Performance, 27, 763-797. doi:10.1037/0096-1523.27.4.763
Salomon, G., \& Almog, T. (1998). Educational psychology and technology: A matter of reciprocal relations. Teachers College Record, 100, 222-241.

Schwartz, B. (2004). The paradox of choice: Why more is less. New York, NY: Ecco.

Selwyn, N. (2009). The digital native - myth and reality. Aslib Proceedings: New Information Perspectives, 61, 364-379. doi:10.1108/00012530910973776

Stahl, S. (1999). Different strokes for different folks? A critique of learning styles. American Educator, 23(3), 27-31.

Stefanou, C. R., Perencevich, K. C., Dicintio, M., \& Turner, J. C. (2004). Supporting autonomy in the classroom: Ways teachers encourage student decision making and ownership. Educational Psychologist, 39, 97-110. doi:10.1207/s15326985ep3902_2

Sternberg, R. J., Grigorenko, E. L., Ferrari, M., \& Clinkenbeard, P. (1999). A triarchic analysis of an aptitude-treatment interaction. European Journal of Psychological Assessment, 15, 1-11. doi:10.1027//1015-5759.15.1.3

Strayer, D. L., Drews, F. A., \& Crouch, D. L. (2006). A comparison of the cell phone driver and the drunk driver. Human Factors: The Journal of the Human Factors and Ergonomics Society, 48, 381-391. doi:10.1518/001872006777724471

Sweller, J., van Merriënboer, J. J. G., \& Paas, F. (1998). Cognitive architecture and instructional design. Educational Psychology Review, 10, 251-296. doi:10.1023/A:1022193728205

Taminiau, E. M. C., Kester, L., Corbalan, G., Alessi, S. M., Moxnes, E., Gijselaers, W. H., . . van Merriënboer, J. J. G. (2013). Why advice on task selection may hamper learning in on-demand education. Computers in Human Behavior, 29, 145-154. doi:10.1016/j.chb.2012.07.028

Tapscott, D. (1997). Growing up digital: The rise of the net generation. New York, NY: McGraw-Hill.

Tombu, M. N., Asplund, C. L., Dux, P. E., Godwin, F. D., Martin, J. W., \& Marois, R. (2011). A unified attentional bottleneck in the human brain. Proceedings of the National Academy of Sciences USA, 108, 13426-13431. doi:10.1073/pnas.1103583108

Twain, M. (2010). Autobiography of Mark Twain, the authentic original version. Lexington, KY: Seven Treasures. (Original work published 1910).

Valtonen, T., Pontinen, S., Kukkonen, J., Dillon, P., Väisänen, P., \& Hacklin, S. (2011). Confronting the technological pedagogical knowledge of Finnish Net Generation student teachers. Technology, Pedagogy and Education, 20, 3-18. doi:10.1080/1475939X.2010.534867

Van Hout-Wolters, B. H. A. M., Simons, P. R. J. \& Volet, S. (2000). Active learning: selfdirected learning and independent work. In P. R. J. Simons, J. L. van der Linden, \& T. M. Duffy (Eds.), New learning (pp. 21-36). Dordrecht, The Netherlands: Kluwer.

van Merriënboer, J. J. G. (1990). Instructional strategies for teaching computer programming: Interactions with the cognitive style reflectionimpulsivity. Journal of Research on Computing in Education, 23, 45-53.

van Merriënboer, J. J. G. (1997). Training complex cognitive skills: A fourcomponent instructional design model for technical training. Englewood Cliffs, NJ: Educational Technology Publications.

van Merriënboer, J. J. G., Jelsma, O., Timmermans, J., \& Sikken, J. (1989). Computerized vs. experimenter controlled administration of the Matching Familiar Figures Test: Mean test scores and reliabilities. Educational and Psychological Measurement, 49, 883-892. doi: $10.1177 / 001316448904900411$

van Merriënboer, J. J. G., \& Kirschner, P. A. (2007). Ten steps to complex learning. Mahwah, NJ: Erlbaum.

van Merriënboer, J. J. G., \& Kirschner, P. A. (2013). Ten steps to complex learning (2nd Rev. ed.). New York, NY: Taylor \& Francis.

van Merriënboer, J. J. G., \& Sweller, J. (2005). Cognitive load theory and complex learning: Recent developments and future directions. Educational Psychology Review, 17, 147-177. doi:10.1007/s10648005-3951-0

Veen, W. (2006). Homo Zappiens. Retrieved from http://www.hanson experience.com/blog/2006/12/slides_van_de_p.html

Veen, W., \& Vrakking, B. (2006). Homo Zappiens: Growing up in a digital age. London, UK: Network Continuum Education. 
Veenman, M. V. J., Prins, F. J., \& Verheij, J. (2003). Learning styles: Selfreports versus thinking-aloud measures. British Journal of Educational Psychology, 73, 357-372. doi:10.1348/000709903322275885

Veugelers, W. (2004). Between control and autonomy: Restructuring secondary education in the Netherlands. Journal of Educational Change, 5, 141-160. doi:10.1023/B:JEDU.0000033070.80545.01

Voogt, J., \& Pareja-Roblin, N. (2010). 21st century skills: Discussion paper. Enschede, The Netherlands: University of Twente. Retrieved from http://onderzoek.kennisnet.nl/attachments/+2185119/White_Paper_

21stCS_Final_ENG_def2.pdf

Wallace, R. M., Kupperman, J., Krajcik, J., \& Soloway, E. (2000). Science on the web: Students online in a sixth-grade classroom. Journal of the Learning Sciences, 9, 75-104. doi:10.1207/s15327809j1s0901_5

Wallis, C. (2006, March 27). The multitasking generation. Time, 13, 3-5.
Walraven, A., Brand-Gruwel, S., \& Boshuizen, H. P. A. (2008). Informationproblem solving: A review of problems students encounter and instructional solutions. Computers in Human Behavior, 24, 623-648. doi:10.1016/j.chb.2007.01.030

Williams, M. D. (1996). Learner-control and instructional technologies. In D. H. Jonassen (Ed.), Handbook of research for educational communications and technology (pp. 957-983). New York, NY: Macmillan.

Williams, P., \& Rowlands, I. (2007). Information behaviour of the researcher of the future: Work package II. London, UK: University College London.

Wolf, S. E., Brush, T., \& Saye, J. (2003). Using information problem-solving model as a metacognitive scaffold for multimedia-supported informationbased problems. Journal of Research on Technology in Education, 35, 321-341 